\title{
Melatonin Mediates Enhancement of Stress Tolerance in Plants
}

\author{
Biswojit Debnath ${ }^{1,2}{ }^{\oplus}$, Waqar Islam ${ }^{3}$, Min Li ${ }^{1}$, Yueting Sun ${ }^{1}$, Xiaocao Lu ${ }^{1}$, Sangeeta Mitra ${ }^{1}$, \\ Mubasher Hussain ${ }^{1}{ }^{\mathbb{D}}$, Shuang Liu ${ }^{1}$ and Dongliang Qiu ${ }^{1, *}$ \\ 1 College of Horticulture, Fujian Agriculture and Forestry University, Fuzhou, Fujian 350002, China; \\ biswo26765@yahoo.com (B.D.); liminzyl@sina.com (M.L.); yuetingsun@126.com (Y.S.); \\ xc531599541@126.com (X.L.); sangeeta.dae@hotmail.com (S.M.); mubasherhussain05uaf@yahoo.com (M.H.); \\ liushuangsyau@aliyun.com (S.L.) \\ 2 Department of Horticulture, Sylhet Agricultural University, Sylhet 3100, Bangladesh \\ 3 College of Geographical Sciences, Fujian Normal University, Fuzhou, Fujian 350007, China; \\ ddoapsial@yahoo.com \\ * Correspondence: qiud11970@fafu.edu.cn; Tel.: +86-13605948966
}

Received: 12 January 2019; Accepted: 22 February 2019; Published: 27 February 2019

\begin{abstract}
Melatonin is a multifunctional signaling molecule, ubiquitously distributed in different parts of plants and responsible for stimulating several physiological responses to adverse environmental conditions. In the current review, we showed that the biosynthesis of melatonin occurred in plants by themselves, and accumulation of melatonin fluctuated sharply by modulating its biosynthesis and metabolic pathways under stress conditions. Melatonin, with its precursors and derivatives, acted as a powerful growth regulator, bio-stimulator, and antioxidant, which delayed leaf senescence, lessened photosynthesis inhibition, and improved redox homeostasis and the antioxidant system through a direct scavenging of reactive oxygen species (ROS) and reactive nitrogen species (RNS) under abiotic and biotic stress conditions. In addition, exogenous melatonin boosted the growth, photosynthetic, and antioxidant activities in plants, confirming their tolerances against drought, unfavorable temperatures, salinity, heavy metals, acid rain, and pathogens. However, future research, together with recent advancements, would support emerging new approaches to adopt strategies in overcoming the effect of hazardous environments on crops and may have potential implications in expanding crop cultivation against harsh conditions. Thus, farming communities and consumers will benefit from elucidating food safety concerns.
\end{abstract}

Keywords: endogenous melatonin; exogenous melatonin; growth regulator; bio-stimulator; antioxidants; oxidative stress

\section{Introduction}

Melatonin ( $\mathrm{N}$-acetyl-5-methoxytryptamine) has an indole ring structure, low molecular weight, and is an evolutionarily conserved pleiotropic molecule that exists ubiquitously in living organisms [1]. It has been recognized that melatonin plays a significant role in animals and plants, particularly in different human processes including generation, sleep regulation, circadian rhythms, retina physiology, sexual behavior, seasonal reproductive physiology, immunological enhancement, and aging [2-5]. The pleiotropic biological activities of melatonin in living organisms are mediated by membrane receptors and nuclear receptors [6,7]. In addition, melatonin receptors act independently [8], and their bioactive metabolites influence the exchange of melatonin with reactive oxygen species (ROS) and reactive nitrogen species (RNS) [9].

Melatonin has an amphiphilic or amphipathic molecular character. It can easily pass through the cell membrane and dispense to the cytosol, the nucleus, and mitochondria [10]. The amphiphilic 
character specifies that the membrane receptor is not inevitably essential for facilitating melatonin actions. In fact, melatonin plays an important role in non-receptor-mediated activities such as scavenging ROS and RNS and improving antioxidant capacity, preventing cells, tissues, and organisms from oxidative stress [11-13]. Subsequently, the formation and absorption of ROS and/or RNS are elementary process associated with cellular biology and physio-pathology Thus, it is assumed that the primary role of melatonin in living organisms is to improve antioxidant activities and act as a first-line defense against any hazardous conditions [14].

Several successive studies have quantified the presence of melatonin in roots, stems, leaves, flowers, fruits, bulbs, and seeds of many plants such as tomatoes, cucumbers, bananas, apples, onions, rice, and so on [15]. It was observed that the content of melatonin enumerated in plant samples differed regularly between cultivars, species, growth and developmental periods, tissue categories, and even in repeats of a single experiment [16].

In the last few years, the role of melatonin in plants has been studied progressively. Biotic and abiotic stressors in plants cause growth obstruction, senescence, yield lessening, and even death. The plant develops different physiological activities to lessen the loss induced by means of various stressors. It has been established that melatonin is involved in improving physiological processes, for example, spreading the plant's normal growth as well as shielding emergent tissues from injury and stress signals from environmental hazards [16-21]. In addition, recent reviews have described the significant characteristics of melatonin in plant behavioral responses against environmental stress $[4,22]$.

Taking into consideration the new progress in melatonin studies in recent years, the activity of melatonin in plants has been comprehensively and intensely explored. In addition, the mechanisms of action associated with melatonin have progressively been revealed. In the current review, the availability of melatonin in different parts of plants and the biosynthesis pathway of melatonin in plants are summarized. In addition, we focus herein on the growing and developmental parameters, abiotic and biotic stress responses of melatonin in plants, and the mitigation impacts of exogenous melatonin on plant responses to environmental stress features and/or plant-pathogen contacts. Notably, the significance and scope of melatonin research in plants is speculated, which might be supportive and insightful for existing research, and determine the imminent route of melatonin study in plants.

\section{History of Melatonin in Plants}

Melatonin was first discovered in the bovine pineal gland of cows in 1958, and was made known to be the source of melanosome content in vertebrates and fish melanophores [23]. Nowadays, melatonin is one of the widely reviewed natural molecules in living organisms, extending from bacteria to mammals $[1,20]$. In the first four decades from its discovery, melatonin became well-known as an animal hormone, and research mainly focused on the physiological role of melatonin. Later on, melatonin research focused on dynamic influences including darkness signals [24], transferring communication towards the brain and marginal organs, and acting as a self-coordinator for biological rhythms such as the biological clock and periodic imitation [25]. Research also focused on its palliative properties in many disorders [26], including Alzheimer's and Parkinson's syndrome [27], glaucoma, multiple sclerosis, depression, insomnia, chronic fatigue syndrome, schizophrenia, anxiety, metabolic syndrome, osteoporosis, and some forms of cancer [28].

However, in the earlier stages, very few observations on the effects of melatonin in eukaryotic plant cells, such as in endosperm cells of bulbous plants [29] and in epidermal cells of onions [30], were given a new direction of study. Thirty years after the discovery of melatonin in mammals, melatonin was found in the single-celled dinoflagellates and finally transformed its research like the methoxyindole [31]. Although melatonin has been recognized in Japanese morning glories (Pharbitis nil) in 1993, its results were not published comprehensively until 1995 [32]. Interestingly, two clear verifications in 1995 pointed to melatonin existence in higher plants [33,34]. In 2003, 108 Chinese 
medical herbs were selected to determine melatonin content. Melatonin was found in all herbs, with levels ranging from limited nanograms to numerous thousand nanograms per gram of tissue [35]. These huge variances exhibited between the species suggest that the function of melatonin in plants must be varied. After that, several successive studies (Table 1) confirmed the occurrence of melatonin in different plants, even in different parts of individual plant $[15,20]$.

Table 1. Availability of melatonin in different plant parts.

\begin{tabular}{|c|c|c|c|c|c|c|c|c|}
\hline \multirow[b]{2}{*}{ Plant Name } & \multirow[b]{2}{*}{ Family } & \multicolumn{6}{|c|}{ Plant Parts } & \multirow[b]{2}{*}{ Reference } \\
\hline & & ङँ & $\begin{array}{l}\vec{ః} \\
\dot{\$}\end{array}$ & 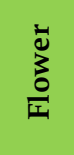 & 壱 & $\begin{array}{l}\stackrel{0}{\vec{z}} \\
\frac{0}{0} \\
\frac{0}{0}\end{array}$ & 苂 & \\
\hline Alfalfa & Fabaceae & & & & & & & [36] \\
\hline Almond & Rosaceae & & & & & & & [37] \\
\hline Aloevera & Asphodelaceae & & & & & & & [35] \\
\hline Anise & Apiaceae & & & & & & & {$[38]$} \\
\hline Apple & Rosaceae & & & & & & & [39] \\
\hline Arabidopsis & Brassicaceae & & & & & & & [40] \\
\hline Banana & Musaceae & & & & & & & [41] \\
\hline Barley & Poaceae & & & & & & & [42] \\
\hline Beet & Amaranthaceae & & & & & & & [33] \\
\hline Broccoli & Brassicaceae & & & & & & & [36] \\
\hline Cabbage & Brassicaceae & & & & & & & [36] \\
\hline Canary grass & Poaceae & & & & & & & [42] \\
\hline Carrot & Apiaceae & & & & & & & [39] \\
\hline Celery & Apiaceae & & & & & & & [38] \\
\hline Cherry & Rosaceae & & & & & & & [43] \\
\hline Chilies & Solanaceae & & & & & & & [44] \\
\hline Chinese liquorice & Fabaceae & & & & & & & [39] \\
\hline Coriander & Apiaceae & & & & & & & [45] \\
\hline Corn & Poaceae & & & & & & & [45] \\
\hline Cucumber & Cucurbitaceae & & & & & & & [39] \\
\hline Fennel & Apiaceae & & & & & & & [38] \\
\hline Fenugreek & Fabaceae & & & & & & & [38] \\
\hline Fever few & Asteraceae & & & & & & & [46] \\
\hline Garlic & Amaryllidaceae & & & & & & & [39] \\
\hline Grape & Vitaceae & & & & & & & [47] \\
\hline Green cardamom & Zingiberaceae & & & & & & & [38] \\
\hline Ginger & Zingiberaceae & & & & & & & [39] \\
\hline Huang-qin & Lamiaceae & & & & & & & [37] \\
\hline Kiwifruit & Actinidiaceae & & & & & & & [34] \\
\hline Lupin & Fabaceae & & & & & & & [41] \\
\hline Maize & Poaceae & & & & & & & [39] \\
\hline Mango & Anacardiaceae & & & & & & & [48] \\
\hline Milk thistle & Asteraceae & & & & & & & [38] \\
\hline Morning glory & Convolvulaceae & & & & & & & [49] \\
\hline Mung bean & Fabaceae & & & & & & & [36] \\
\hline Mustard & Brassicaceae & & & & & & & [38] \\
\hline Oat & Poaceae & & & & & & & [42] \\
\hline Onion & Amaryllidaceae & & & & & & & [36] \\
\hline
\end{tabular}


Table 1. Cont.

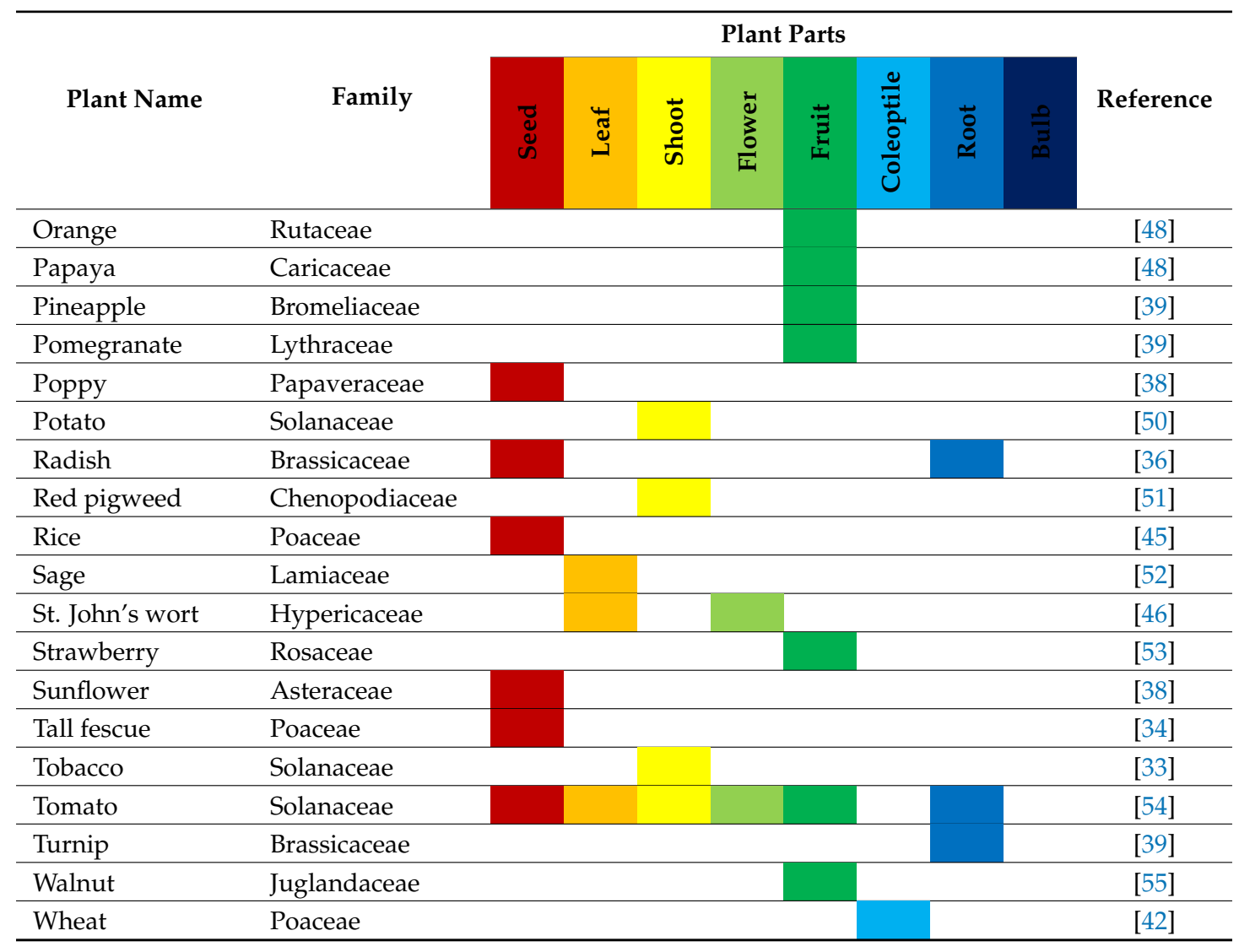

\section{Biosynthesis of Melatonin in Plants}

In general, melatonin can be transformed enzymatically, pseudo-enzymatically, or nonenzymatically into a number of biologically active metabolites such as 5-MT (5-methoxytryptamine), c3OH M (cyclic 3-hydroxymelatonin), AFMK (N1-acetyl-N2-formyl-5-methoxykynuramine), and AMK (N1-acetyl-5-methoxykynuramine) [14,56]. In addition, melatonin degraded to AFMK by numerous enzymes such as IDO (indoleamine 2,3-dioxygenase), EPO (eosinophil peroxidase), HRP (horseradish peroxidase), MPO (myeloperoxidase), CYP (cytochrome $\mathrm{P}_{450}$ ) subforms, and $\mathrm{NQR}_{2}$. Furthermore, reference [56] reported the particulars and additional paths of AFMK and AMK formation. Interestingly, CYPs interchangeably break down melatonin to OHM (6-hydroxymelatonin), NAS ( $N$-acetylserotonin), or AFMK [14]. The biologically active metabolites of melatonin prominently enlarged the range of this universally acting indoleamine $[9,56]$.

In the case of plants, Murch and Saxena [46] observed that 5-hydroxytryptophan is involved in serotonin synthesis in the flowering plant Hyericum perforatum L. (namely Saint John's wort), similar to vertebrates. However, another study on rice indicated that the conversion of serotonin occurred markedly through tryptophan-tryptamine-serotonin, known as the tryptamine pathway. Subsequently, this pathway has been commonly observed in several plant species [57]. Interestingly, in plants as well in animals serotonin is transformed to NAS, which is further catalyzed by SNAT (serotonin $\mathrm{N}$-acetyltransferase) and HIOMT (methylated via hydroxyindole-O-methyltransferase), and is recognized as ASMT (acetyl serotonin methyl transferase) and ensures melatonin creation. In addition, $N$-acetyl serotonin is formed in plants from tryptamine, where $N$-acetyltryptamine assists as a transitional product, and is assembled by HIOMT/ASMT and SNAT [58,59]. In the meantime, indole acetic acid is formed from tryptamine, and indole-3-acetylaldehyde acts equally as a middle product [58]. 
In brief, as shown in Figure 1, the standard pathway of melatonin biosynthesis from tryptophan in plants involves four steps: first, TDC (decarboxylation by tryptophan decarboxylase); second, T5H (amine hydroxylation by tryptamine 5-hydroxylase) to serotonin; third, $\mathrm{N}$-acetylation through SNAT (serotonin $N$-acetyltransferase), which activates the similar reaction AANAT (non-homologous aralkylamine $\mathrm{N}$-acetyltransferase) of vertebrates; and finally, the $\mathrm{O}$-methylation to melatonin via ASMT ( $\mathrm{N}$-acetylserotonin $\mathrm{O}$-methyltransferase) $[60,61]$.

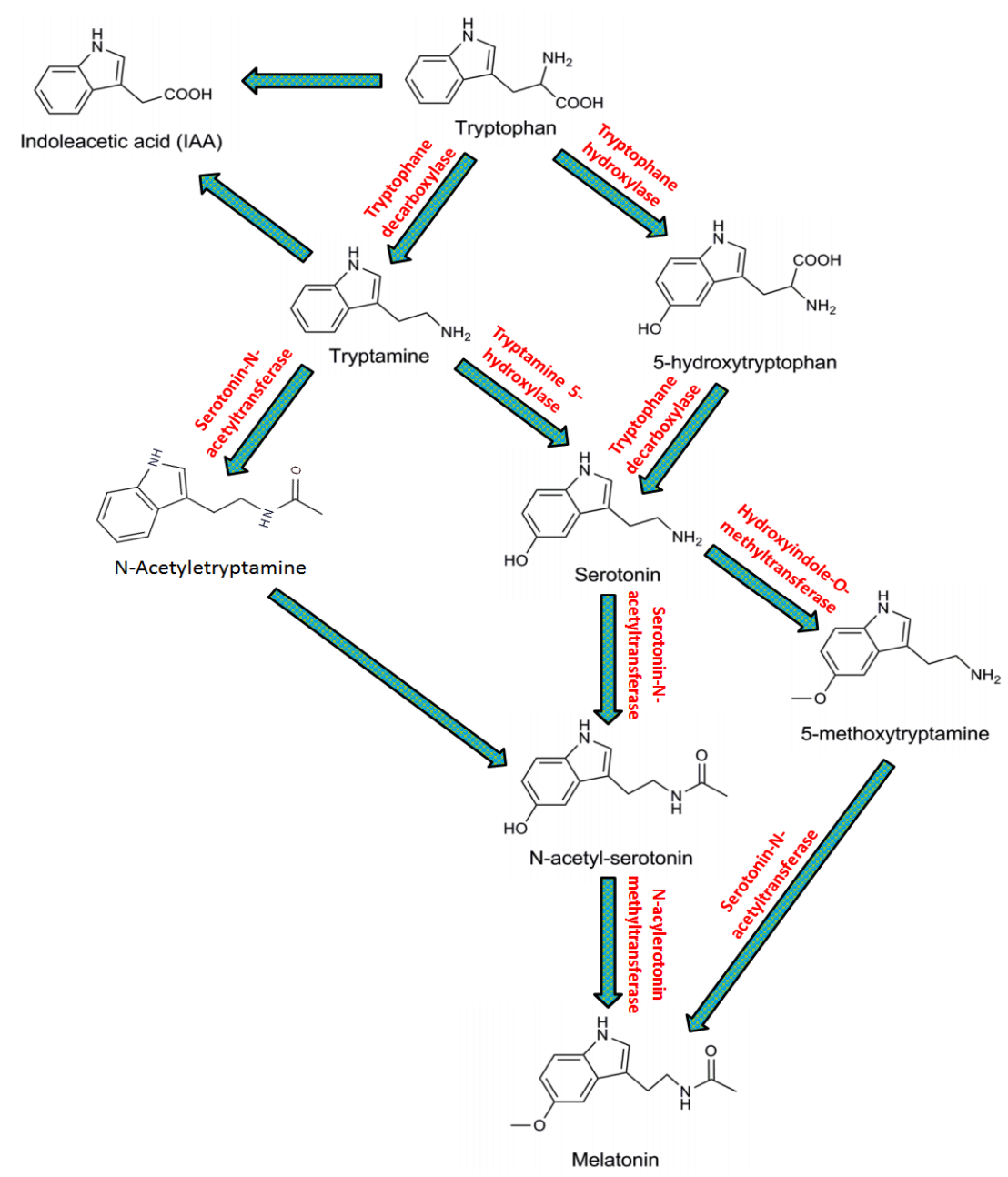

Figure 1. Biosynthesis of melatonin in plants. Modified from Zhang et al. [62].

\section{Melatonin Acts as a Plant Growth Regulator}

The chemical compounds that are synthesized artificially and act as plant hormones in regulating the growth of cultivated plants, weeds, and in-vitro grown plants and plant cells are usually known as plant growth regulators. In recent years, numerous studies have promoted that melatonin can be one of the core actors in the response mechanism and might have significant capabilities in plant physiology under adverse environments. The concentrations of melatonin were differed extensively in different plant species, even in different plant parts of same species. This undeniably concludes that melatonin must have diverse functions by means of growth regulators in plants [20]. The auxin plays a diverse role in plant growth and development, and Indole-3-acetic acid (IAA) is considered a most common auxin. Structurally, melatonin and IAA showed many similarities such as a planar aromatic ring, a carboxylic acid-binding site, and a hydrophobic transition region. Evidently, both melatonin and IAA could partially contribute to varied physiological processes relating to plant growth and development, and antioxidant potentials as well [63]. Melatonin acts as a growth developer in Lupinus albus (as like IAA), and encourages the vigorous growth of hypocotyls at micromolar accumulations, even though it 
has inhibitory consequences at higher accumulations [58]. Compared to IAA, the impact of melatonin on growth promotion is $63 \%$ greater, which is considered a significant auxinic outcome [50]. Similarly, the assessment of melatonin on growth promotion in other plants, such as numerous monocots, oats, wheat, barley, and canary grasses, ranged from $10 \%$ to $55 \%$ relative to IAA. Moreover, similar to IAA, the growth restrictive effects of melatonin on the roots of canary grass and wheat were about $56 \%$ and $86 \%$, respectively, compared to IAA [42]. The authors [64] in Brassica observed that the lower accumulation of melatonin prompted the IAA biosynthesis, which resulted in the encouragement of root growth, though the particular association between IAA and melatonin is not clear yet. In addition, the melatonin effect on the stimulation of rhizogenesis was primarily confirmed in 2007 . The induction of adventitious or lateral roots in lupin, prompted through the consequence of melatonin, persuaded root primordials from pericycle cells. Recently, it has been confirmed that the rhizogenic effect was noticeable in cucumbers, cherry rootstocks, rice, and pomegranates [58].

Additionally, melatonin had a significant influence as a plant growth regulator in cell culture. The endogenous level of melatonin in the culture medium of in-vitro culture explants of Hypericum perforatum modified the plant morphogenesis, altering auxin-induced rhizogenesis and cytokinin-induced caulogenesis, indicating that melatonin had a potential impact on plant growth regulation and auxin modulation [65,66]. Moreover, it has been observed that the rice IDO (indoleamine 2,3-dioxygenase) gene showed over expression in transgenic tomatoes, indicating auxin-like action of melatonin in apical dominance and branching [67]. Interestingly, low levels of biosynthetic melatonin over expressed the OID gene in transgenic tomato plants, leading to lateral leaflet pattern changes, a drop in leaflet number, as well as less firm and more serrated leaves compared to wild type. However, over expression of SNAT and HIOMT in tomato plants attributed higher melatonin levels in leaves, and led to a considerable decline in endogenous IAA levels because of tryptophan, a common ancestor of melatonin and IAA [68].

Although the numerous functions of melatonin have been scrutinized thoroughly in higher plants, the data are limited in its altogether role. In summary, several studies recommended exact physiological actions of melatonin in plants, such as stimulating the growth of different seedlings [42,69], triggering or preventing the growth of primary roots $[69,70]$, encouraging lateral and adventitious rooting in different species [70,71], adjusting branching and growth patterns of stems and leaves [68], inhibiting delay-induced leaf senescence through enhancing photosynthesis, $\mathrm{CO}_{2}$ uptake, and biomass accumulation [57,72], stimulating rhizogenesis and caulogenesis in explant cultures [66,73], effects on flowering [74], and altered levels during fruit development and seed formation [54,75].

\section{Melatonin Acts as a Bio-Stimulator and an Antioxidant in Plants}

Plants are sessile, but they can modify their own physiological condition to adjust to harsh environmental conditions. In any plant challenged to an unfavorable environment, a quick and remarkable variation arises inside the plant cells to stay alive. Thus, different bio-stimulators are activated in the adjustment to the harsh environment to encourage the prevailing capabilities of bioremediation. Likewise, melatonin can boost the physiological activity against adverse environments as an efficient antioxidant compound. More than 25 years ago, it was found that melatonin acts as an uninterrupted free radical scavenger [76]. Melatonin is one type of amphiphilic indole ring structure compound, and it moves without difficulty via cell membranes to the cytoplasm. It can also pass subcellular partitions due to its amphipathic indole ring structure. For these reasons it is called an ecologically friendly molecule, having wide ranges in antioxidant capacity [77,78]. Normally, a cell is isolated from its adjacent surroundings by the plasma membrane. This physical barrier (plasma membrane) is particularly absorbent to small molecules (even to ions), but melatonin crosses the barrier easily due to its amphipathic nature [62]. Similarly, cyclic 3-hydroxymelatonin has antioxidant properties that are capable of counteracting the extremely toxic hydroxyl radical $(\mathrm{OH} \bullet)$. The reaction of melatonin with hydrogen peroxide was shown in vitro in 2000 by Tan et al., and it was reported that its product also had antioxidant properties [79]. Melatonin is also known to scavenge the superoxide 
$\left(\mathrm{O}^{2-}\right)$ [80]. These scavenging activities occurred due to the surprisingly extraordinary competence of melatonin in dropping radical loss in vivo [81]. Poeggeler et al. [82] stated that melatonin is five times more effective than glutathione (GSH) in neutralizing hydroxide $\left(\mathrm{OH}^{-}\right)$and 15-fold more effective than the exogenous scavenger mannitol.

Besides the role of melatonin in directly scavenging numerous free radicals, ROS, and RNS, it also acts as a signaling molecule at the cellular level and up-regulates a number of antioxidant enzymes, which increases its efficiency as an antioxidant [83]. The interaction between melatonin and ROS in plants indicates the function of melatonin as an effective antioxidant through both direct and indirect mechanisms. Melatonin signal transmission acts on ROS-mediated signals such as the balancing of hydrogen peroxide $\left(\mathrm{H}_{2} \mathrm{O}_{2}\right)$. Melatonin acts as a direct antioxidant and is proficient in lowering the levels of reactive oxygen compared to ascorbic acid. Various melatonin metabolites, such as 3-OHM, AFMK, and 2-hyxdroxymelatonin, also act by means of influential antioxidants, promoting the antioxidant capabilities of this biomolecule [84]. Remarkably, melatonin is not limited by any prerequisite for an exact recovering pathway or any supplementary metabolites for accomplishment of a redox cycle $[85,86]$. Melatonin acts as a mediator in different antioxidant pathways, for example, the glutathione ascorbate cycle, peroxidases, superoxide dismutase, and catalase through varied mechanisms, resulting in abiotic and biotic stress responses in the plant [22,87]. Moreover, reactive nitrogen species, for example, nitric oxide, are also detoxified by melatonin [88].

It was hypothesized that the pathway formed with melatonin can play a significant role in reclaiming ROS and RNS intended for comeback from growing atmospheric oxygenation $[4,60]$. The melatonin and ROS interface acts as a vital and fast signaling molecule within plants when ROS arises $[89,90]$. Therefore, based on several findings, it can be summarized that there is a dynamic association between melatonin and electrical, ionic, and chemical signaling pathways, which results in adaptive activities and a transformed plant metabolism for developing tolerance to hazardous environments (Figure 2).

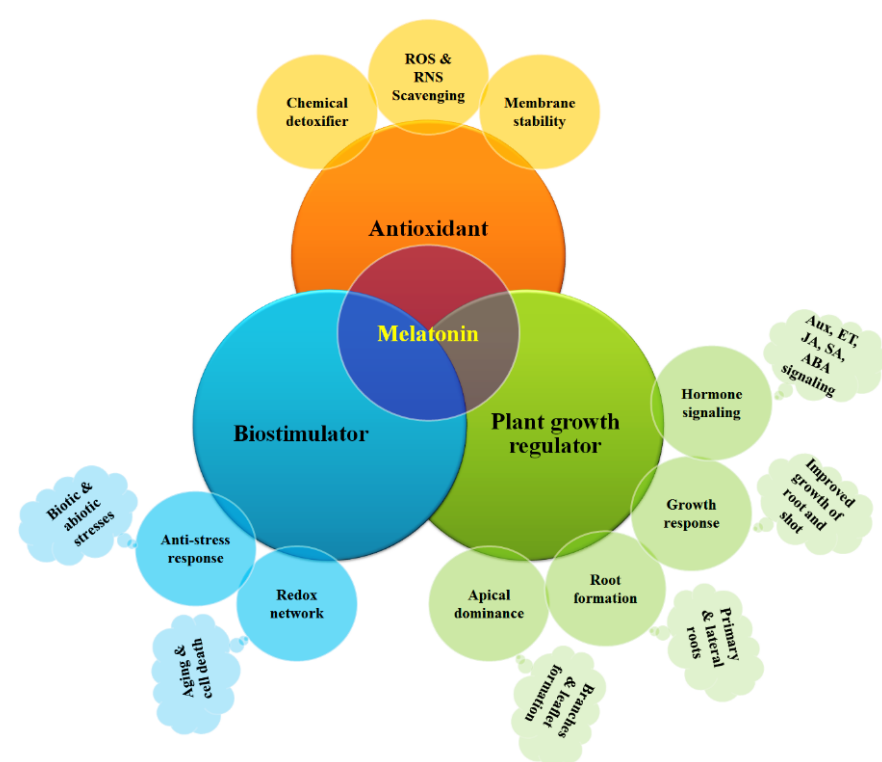

Figure 2. Mechanism of melatonin activities in plants as a growth regulator, bio-stimulator, and antioxidant. Here, ROS, RNS, Aux, ET, JA, SA, ABA indicates reactive oxygen species, reactive nitrogen species, auxin, ethylene, jasmonic acid, salicylic acid, and abscisic acid, respectively.

\section{Exogenous Melatonin and Plant Stress Tolerance}

Recently, the impact of exogenous melatonin on plant defense systems to cope with biotic and abiotic stress has attracted the attention of the researchers worldwide. Although the pathways of melatonin synthesis in plants and its metabolic mechanisms are still unclear, researchers still believe 
that melatonin production in plants is a universal fact. Relatively greater levels of melatonin in plants results in production of RNS and ROS, which in turn, plays an important role in plant tolerance against adverse environmental conditions [91]. The detoxification system in plants fails to completely degrade some foreign compounds, which leads to the increased level of toxicity in plants [92]. Melatonin developed a new era in plant adaptation mechanisms. Therefore, studying exogenous melatonin in stressed plants, in terms of plant adaptation and survival, has been gaining extensive consideration in researcher. Recently, it has been confirmed that exogenous melatonin improves the tolerance against salt, drought, and cold stress in Bermuda grass [93]. In some plant species, the impact of exogenous melatonin, regarding stress management, is dose dependent [62]. In Brassica juncea, Chen et al. [64] demonstrated that root growth was stimulated in response to low concentrations of melatonin $(0.1 \mathrm{mM})$, whereas a high concentration $(100 \mathrm{mM})$ inhibited root growth. Similar results were also observed in cherry tissue culture [71]. They demonstrated that melatonin administration at high concentrations declined in total biomass content, which could be explained by the influence that melatonin at high concentrations has in decreasing the endogenous level of promoters. A number of authors showed that melatonin application substantially alleviated abiotic and biotic stress responsive reduction in growth, biomass accumulation, chlorophyll loss, photosynthetic inhibition, and antioxidant activities in several plants, as described in Table 2. It has been demonstrated that glutathione peroxidase (GPX), glutathione reductase (GR), $\mathrm{Zn}, \mathrm{Cu}$ and / or Mn-SOD, peroxidase (POD), and catalase (CAT) activities were up-regulated as free radical scavengers to reduce ROS in plant cells through exogenous melatonin. They also reported that exogenous melatonin not only protected against ROS, but also protected the proteins related to chlorophyll and photosynthesis. They further mentioned that the increase in efficiency was due to the better working of photosystem II, having a larger number of open reaction centers that are better for the function of all the photosynthetic transport chain members under melatonin treatment. Remarkably, exogenous melatonin prevented the loss of chlorophylls, and it could be explained by the stimulation of Fe uptake and the subsequent increase in ferrodoxins, which regulate the amount of reduced ascorbate and protect chlorophyll from degradation [94]. They also reported that melatonin results in suppression of salt-induced inhibition and enhancement of the ferrodoxins gene PetF in soybeans. Exogenous melatonin also protects cell ultrastructure. Recently, reference [95] demonstrated that seed priming with melatonin produced seedlings with a $20 \%$ increase in root length and improved and organized cell ultrastructure. Similarly, recovery of leaf ultrastructures through exogenous melatonin have been observed in tomatoes that were stressed in acid rain conditions [17].

In addition, melatonin transgenic plants have transformed, or act together with, other phytohormones to further adjust different growing processes in hostile environments. For example, application of melatonin boosted the root growth and development of transgenic rice plants [70]. Moreover, it was observed that rice ASMT-mRNA was markedly expressed after abscisic acid and methyl jasmonic acid treatments, specifying the potential involvement of melatonin under different stress conditions [96]. Therefore, the evidence from different observations suggested that transgenic plants conveying melatonin biosynthesis genes have generated physiological activities and improved stress tolerance abilities of plants under unfriendly conditions [97,98].

Moreover, exogenous melatonin modulated the expression of numerous genes in plants [62,99]. Interestingly, it was also observed that the genes controlled by low melatonin concentrations might not be controlled by high melatonin concentrations [99]. Genome-wide transcriptomic profiling revealed that genes were differentially expressed in melatonin-treated plants, compared to controls. Gene ontology enrichment studies characterized various genes related to different primary and secondary plant physiological metabolisms (nitrogen metabolism, carbohydrate metabolism, tri-carboxylic acid transformation, transport, hormone metabolism, metal handling, and redox) in melatonin pre-treated plants. Melatonin plays a pivotal role in the regulation of several specific stress related genes. For example, chlorophyll content may be preserved via melatonin, and the light-regulating enzyme associated with chlorophyll degradation, namely chlorophyllase (CLH1), was significantly down-regulated with melatonin treatment in Arabidopsis [99]. Other research also 
reported that inhibited pheide-a-oxygenase (PAO) transcript levels were inhibited via exogenous melatonin. PAO is another vital enzyme that degrades chlorophyll [100]. In agreement with these findings, Zhang et al. [62] confirmed that exogenous melatonin plays a significant role in protecting chlorophyll content in leaves and also helps in delaying the senescence and boosting photosynthetic rates. Therefore, melatonin, in conjunction with antioxidant enzymes, improves photosynthesis, delays leaf senescence, slows alterations in the leaf ultrastructure, delays biosynthesis of metabolites, and modulates stress genes to form an efficient system that protects plants from harsh environments. All these outcomes suggest that melatonin has an imperative role in coping with harsh environmental conditions.

Table 2. Exogenous melatonin improves abiotic and biotic stress tolerance in different plants.

\begin{tabular}{|c|c|c|}
\hline $\begin{array}{l}\text { Crops Name } \\
\text { (Scientific Name) }\end{array}$ & Family & Different Stress Tolerances \\
\hline $\begin{array}{l}\text { Arabidopsis } \\
\text { (Arabidopsis thaliana) }\end{array}$ & Brassicaceae & $\begin{array}{l}\text { Salinity [101]; Drought [98]; High temperature [83]; Low } \\
\text { temperature [102]; Pathogen [88] }\end{array}$ \\
\hline $\begin{array}{l}\text { Rapeseed } \\
\text { (Brassica napus L.) }\end{array}$ & Brassicaceae & Drought [103] \\
\hline $\begin{array}{l}\text { Tomato } \\
\text { (Solanum lycopersicum) }\end{array}$ & Solanaceae & $\begin{array}{l}\text { Salinity [104]; Sodic Alkaline [105]; Drought [106]; High } \\
\text { temperature [107]; Low temperature [108]; Heavy metal [109]; } \\
\text { Acid rain [17] }\end{array}$ \\
\hline $\begin{array}{l}\text { Potato } \\
\text { (Solanum tuberosum) }\end{array}$ & Solanaceae & Pathogen [110] \\
\hline $\begin{array}{l}\text { Cucumber } \\
\text { (Cucumis sativus) }\end{array}$ & Cucurbitaceae & $\begin{array}{l}\text { Salinity [111]; Nitrate [112]; Drought [113]; Low temperature } \\
\text { [114] }\end{array}$ \\
\hline $\begin{array}{l}\text { Watermelon } \\
\text { (Citrullus lanatus) }\end{array}$ & Cucurbitaceae & Salinity [19]; Low temperature [115]; Heavy metal [116] \\
\hline $\begin{array}{l}\text { Rice } \\
\text { (Oryza sativa) }\end{array}$ & Poaceae & Low temperature [117]; Low temperature \& drought [118] \\
\hline $\begin{array}{l}\text { Wheat } \\
\text { (Triticum aestivum) }\end{array}$ & Poaceae & Low temperature [119]; Drought [18]; Heavy metal [120] \\
\hline $\begin{array}{l}\text { Maize } \\
\text { (Zea mays) }\end{array}$ & Poaceae & Salinity [121]; Drought [122] \\
\hline $\begin{array}{l}\text { Ray grass } \\
\text { (Lolium perenne) }\end{array}$ & Poaceae & High temperature [123] \\
\hline $\begin{array}{l}\text { Tall fescue grass } \\
\text { (Festuca arundinacea) }\end{array}$ & Poaceae & High temperature [124] \\
\hline $\begin{array}{l}\text { Naked oat } \\
\text { (Avena nuda L.) }\end{array}$ & Poaceae & Drought [125] \\
\hline $\begin{array}{l}\text { Alfalfa } \\
\text { (Medicago sativa) }\end{array}$ & Fabaceae & Drought [126]; Heavy metal [127]; \\
\hline $\begin{array}{l}\text { Sunflower } \\
\text { (Helianthus annuus) }\end{array}$ & Asteraceae & Salinity [128] \\
\hline $\begin{array}{l}\text { Crabapple } \\
\text { (Malus hupehensis) }\end{array}$ & Rosaceae & Salinity [129]; Alkaline [130] \\
\hline $\begin{array}{l}\text { Peach } \\
\text { (Prunus persica) }\end{array}$ & Rosaceae & Low temperature [131] \\
\hline $\begin{array}{l}\text { Banana } \\
\text { (Musa acuminate) }\end{array}$ & Musaceae & Pathogen [132] \\
\hline $\begin{array}{l}\text { Kiwifruit } \\
\text { (Actinidia deliciosa) }\end{array}$ & Actinidiaceae & High temperature [133] \\
\hline $\begin{array}{l}\text { Tea } \\
\text { (Camellia sinensis L.) }\end{array}$ & Theaceae & Low temperature [134] \\
\hline
\end{tabular}




\section{Conclusions}

Melatonin is a pleiotropic molecule and has amphiphilic properties in plants. The current review discussed the properties of melatonin, and the recent progress in research. Melatonin presents in different parts of the plant, and melatonin biosynthesis leads to the development of crucial functions in plants for surviving against various stresses. Melatonin played an important role in mitigating abiotic and biotic stress directly through scavenging ROS and RNS, and indirectly through recovering leaf ultrastructure, improving the photosynthesis system, stimulating plant growth regulators, and triggering antioxidant activities in plants. Nonetheless, endogenous melatonin, in addition to other natural protectors in plants, is unable to protect plants against severe stress conditions. In this regard, exogenous melatonin showed remarkable coping mechanisms in harsh environments by boosting plant growth regulation, delaying leaf senescence, increasing photosynthesis, and increasing ROS and RNS scavenging antioxidant systems in plants. Meanwhile, the physiological and molecular activities of melatonin in plants indicate that melatonin is an essential molecule in the stimulation of field crops, especially where biotic and abiotic stress is a limiting factor for crop production.

However, there are numerous major issues to be explored. The role of endogenous melatonin and the uses of exogenous melatonin against viruses, nematodes, or insects requires detailed investigations. There is still lack of information available regarding the genes and core pathways that are precisely regulated by melatonin. To conclude, there is enormous research potential for bettering our understanding of the impact that melatonin has in basic life functions across plant kingdoms, and the creation of new approaches to advance progress in plant cultivation and industrial agriculture.

Author Contributions: B.D. conceived, designed and written the manuscript. W.I. revised and helped in figure preparation. M.L., Y.S., X.L., S.M., M.H., and S.L. helped in collection of information and writing the manuscript. D.Q. conceived, reviewed and finalized the manuscripts. All authors approved the published version.

Acknowledgments: We are grateful to the researchers who have contributed to this field. This study was supported by National Natural Science Grant of China (Award no. 30400061), Natural Science Foundation of Fujian Province, China (2011J01082), The Construction of Plateau Discipline of Fujian Province (102/71201801101) and Special Fund for Science and Technology Innovation of FAFU (CXZX2016107).

Conflicts of Interest: The authors declare no conflict of interest.

\section{References}

1. Hardeland, R.; Cardinali, D.P.; Srinivasan, V.; Spence, D.W.; Brown, G.M.; Pandi-Perumal, S.R. Melatonin-A pleiotropic, orchestrating regulator molecule. Prog. Neurobiol. 2011, 93, 350-384. [CrossRef] [PubMed]

2. Yu, K.; Deng, S.-L.; Sun, T.-C.; Li, Y.-Y.; Liu, Y.-X. Melatonin regulates the synthesis of steroid hormones on male reproduction: A review. Molecules 2018, 23, 447. [CrossRef] [PubMed]

3. Tan, D.X.; Xu, B.; Zhou, X.; Reiter, R.J. Pineal calcification, melatonin production, aging, associated health consequences and rejuvenation of the pineal gland. Molecules 2018, 23, 301. [CrossRef] [PubMed]

4. Manchester, L.C.; Coto-Montes, A.; Boga, J.A.; Andersen, L.P.H.; Zhou, Z.; Galano, A.; Vriend, J.; Tan, D.X.; Reiter, R.J. Melatonin: An ancient molecule that makes oxygen metabolically tolerable. J. Pineal Res. 2015, 59, 403-419. [CrossRef] [PubMed]

5. Beilby, M.J.; Turi, C.E.; Baker, T.C.; Tymm, F.J.; Murch, S.J. Circadian changes in endogenous concentrations of indole-3-acetic acid, melatonin, serotonin, abscisic acid and jasmonic acid in characeae (Chara australis Brown). Plant Signal. Behav. 2015, 10, e1082697. [CrossRef] [PubMed]

6. Shiu, S.Y.; Pang, B.; Tam, C.W.; Yao, K.M. Signal transduction of receptor-mediated antiproliferative action of melatonin on human prostate epithelial cells involves dual activation of $\mathrm{g} \alpha \mathrm{s}$ and $\mathrm{g} \alpha \mathrm{q}$ proteins. J. Pineal Res. 2010, 49, 301-311. [CrossRef] [PubMed]

7. Imbesi, M.; Arslan, A.D.; Yildiz, S.; Sharma, R.; Gavin, D.; Tun, N.; Manev, H.; Uz, T. The melatonin receptor $\mathrm{mt} 1$ is required for the differential regulatory actions of melatonin on neuronal 'clock' gene expression in striatal neurons in vitro. J. Pineal Res. 2009, 46, 87-94. [CrossRef] [PubMed]

8. Tan, D.; Reiter, R.J.; Manchester, L.C.; Yan, M.; El-Sawi, M.; Sainz, R.M.; Mayo, J.C.; Kohen, R.; Allegra, M.; Hardeland, R. Chemical and physical properties and potential mechanisms: Melatonin as a broad spectrum antioxidant and free radical scavenger. Curr. Top. Med. Chem. 2002, 2, 181-197. [CrossRef] [PubMed] 
9. Schaefer, M.; Hardeland, R. The melatonin metabolite n1-acetyl-5-methoxykynuramine is a potent singlet oxygen scavenger. J. Pineal Res. 2009, 46, 49-52. [CrossRef] [PubMed]

10. Acuña-Castroviejo, D.; Martín, M.; Macías, M.; Escames, G.; León, J.; Khaldy, H.; Reiter, R.J. Melatonin, mitochondria, and cellular bioenergetics. J. Pineal Res. 2001, 30, 65-74. [CrossRef] [PubMed]

11. Nopparat, C.; Porter, J.E.; Ebadi, M.; Govitrapong, P. The mechanism for the neuroprotective effect of melatonin against methamphetamine-induced autophagy. J. Pineal Res. 2010, 49, 382-389. [CrossRef] [PubMed]

12. Um, H.J.; Kwon, T.K. Protective effect of melatonin on oxaliplatin-induced apoptosis through sustained mcl-1 expression and anti-oxidant action in renal carcinoma caki cells. J. Pineal Res. 2010, 49, 283-290. [CrossRef] [PubMed]

13. Xu, S.C.; He, M.D.; Zhong, M.; Zhang, Y.W.; Wang, Y.; Yang, L.; Yang, J.; Yu, Z.P.; Zhou, Z. Melatonin protects against nickel-induced neurotoxicity in vitro by reducing oxidative stress and maintaining mitochondrial function. J. Pineal Res. 2010, 49, 86-94. [CrossRef] [PubMed]

14. Tan, D.X.; Hardeland, R.; Manchester, L.C.; Paredes, S.D.; Korkmaz, A.; Sainz, R.M.; Mayo, J.C.; Fuentes-Broto, L.; Reiter, R.J. The changing biological roles of melatonin during evolution: From an antioxidant to signals of darkness, sexual selection and fitness. Biol. Rev. 2010, 85, 607-623. [CrossRef] [PubMed]

15. Nawaz, M.A.; Huang, Y.; Bie, Z.; Ahmed, W.; Reiter, R.J.; Niu, M.; Hameed, S. Melatonin: Current status and future perspectives in plant science. Front. Plant Sci. 2016, 6, 1230. [CrossRef] [PubMed]

16. Erland, L.A.; Murch, S.J.; Reiter, R.J.; Saxena, P.K. A new balancing act: The many roles of melatonin and serotonin in plant growth and development. Plant Signal. Behav. 2015, 10, e1096469. [CrossRef] [PubMed]

17. Debnath, B.; Hussain, M.; Irshad, M.; Mitra, S.; Li, M.; Liu, S.; Qiu, D. Exogenous melatonin mitigates acid rain stress to tomato plants through modulation of leaf ultrastructure, photosynthesis and antioxidant potential. Molecules 2018, 23, 388. [CrossRef] [PubMed]

18. Cui, G.; Zhao, X.; Liu, S.; Sun, F.; Zhang, C.; Xi, Y. Beneficial effects of melatonin in overcoming drought stress in wheat seedlings. Plant Physiol. Biochem. 2017, 118, 138-149. [CrossRef] [PubMed]

19. Li, H.; Chang, J.; Chen, H.; Wang, Z.; Gu, X.; Wei, C.; Zhang, Y.; Ma, J.; Yang, J.; Zhang, X. Exogenous melatonin confers salt stress tolerance to watermelon by improving photosynthesis and redox homeostasis. Front. Plant Sci. 2017, 8, 295. [CrossRef] [PubMed]

20. Arnao, M.B.; Hernández-Ruiz, J. Functions of melatonin in plants: A review. J. Pineal Res. 2015, 59, $133-150$. [CrossRef] [PubMed]

21. Meng, J.F.; Xu, T.F.; Wang, Z.Z.; Fang, Y.L.; Xi, Z.M.; Zhang, Z.W. The ameliorative effects of exogenous melatonin on grape cuttings under water-deficient stress: Antioxidant metabolites, leaf anatomy, and chloroplast morphology. J. Pineal Res. 2014, 57, 200-212. [CrossRef] [PubMed]

22. Erland, L.A.; Saxena, P.K.; Murch, S.J. Melatonin in plant signalling and behaviour. Funct. Plant Biol. 2018, 45, 58-69. [CrossRef]

23. Lerner, A.B.; Case, J.D.; Takahashi, Y.; Lee, T.H.; Mori, W. Isolation of melatonin, the pineal gland factor that lightens melanocytes1. J. Am. Chem. Soc. 1958, 80, 2587. [CrossRef]

24. Pandi-Perumal, S.R.; Trakht, I.; Srinivasan, V.; Spence, D.W.; Maestroni, G.J.; Zisapel, N.; Cardinali, D.P. Physiological effects of melatonin: Role of melatonin receptors and signal transduction pathways. Prog. Neurobiol. 2008, 85, 335-353. [CrossRef] [PubMed]

25. Jan, J.E.; Reiter, R.J.; Wasdell, M.B.; Bax, M. The role of the thalamus in sleep, pineal melatonin production, and circadian rhythm sleep disorders. J. Pineal Res. 2009, 46, 1-7. [CrossRef] [PubMed]

26. Wilhelmsen, M.; Amirian, I.; Reiter, R.J.; Rosenberg, J.; Gögenur, I. Analgesic effects of melatonin: A review of current evidence from experimental and clinical studies. J. Pineal Res. 2011, 51, 270-277. [CrossRef] [PubMed]

27. Srinivasan, V.; Pandi-Perumal, S.; Maestroni, G.; Esquifino, A.; Hardeland, R.; Cardinali, D. Role of melatonin in neurodegenerative diseases. Neurotox. Res. 2005, 7, 293-318. [CrossRef] [PubMed]

28. Di Bella, G.; Mascia, F.; Gualano, L.; Di Bella, L. Melatonin anticancer effects. Int. J. Mol. Sci. 2013, 14, 2410-2430. [CrossRef] [PubMed]

29. Jackson, W. Regulation of mitosis: Ii. Interaction of isopropyl n-phenyl-carbamate and melatonin. J. Cell Sci. 1969, 5, 745-755. [PubMed]

30. Banerjee, S.; Margulis, L. Mitotic arrest by melatonin. Exp. Cell Res. 1973, 78, 314-318. [CrossRef] 
31. Poeggeler, B.; Balzer, I.; Hardeland, R.; Lerchl, A. Pineal hormone melatonin oscillates also in the dinoflagellategonyaulax polyedra. Naturwissenschaften 1991, 78, 268-269. [CrossRef]

32. Vantassel, D.; Roberts, N.; Oenill, S. Melatonin from higher-plants-isolation and identification of n-acetyl 5-methoxytryptamine. In Plant Physiology; American Society of Plant Biologists: Rockville, MD, USA, 1995; p. 101.

33. Dubbels, R.; Reiter, R.; Klenke, E.; Goebel, A.; Schnakenberg, E.; Ehlers, C.; Schiwara, H.; Schloot, W. Melatonin in edible plants identified by radioimmunoassay and by high performance liquid chromatography-mass spectrometry. J. Pineal Res. 1995, 18, 28-31. [CrossRef] [PubMed]

34. Hattori, A.; Migitaka, H.; Iigo, M.; Itoh, M.; Yamamoto, K.; Ohtani-Kaneko, R.; Hara, M.; Suzuki, T.; Reiter, R.J. Identification of melatonin in plants and its effects on plasma melatonin levels and binding to melatonin receptors in vertebrates. Biochem. Mol. Biol. International 1995, 35, 627-634.

35. Chen, G.; Huo, Y.; Tan, D.-X.; Liang, Z.; Zhang, W.; Zhang, Y. Melatonin in Chinese medicinal herbs. Life Sci. 2003, 73, 19-26. [CrossRef]

36. Aguilera, Y.; Herrera, T.; Benítez, V.; Arribas, S.M.; de Pablo, A.L.L.; Esteban, R.M.; Martín-Cabrejas, M.A. Estimation of scavenging capacity of melatonin and other antioxidants: Contribution and evaluation in germinated seeds. Food Chem. 2015, 170, 203-211. [CrossRef] [PubMed]

37. Manchester, L.C.; Tan, D.-X.; Reiter, R.J.; Park, W.; Monis, K.; Qi, W. High levels of melatonin in the seeds of edible plants: Possible function in germ tissue protection. Life Sci. 2000, 67, 3023-3029. [CrossRef]

38. Reiter, R.J.; Tan, D.X. Melatonin: An antioxidant in edible plants. Ann. N.Y. Acad. Sci. 2002, 957, 341-344. [CrossRef] [PubMed]

39. Badria, F.A. Melatonin, serotonin, and tryptamine in some egyptian food and medicinal plants. J. Med. Food 2002, 5, 153-157. [CrossRef] [PubMed]

40. Hernández, I.G.; Gomez, F.J.V.; Cerutti, S.; Arana, M.V.; Silva, M.F. Melatonin in Arabidopsis thaliana acts as plant growth regulator at low concentrations and preserves seed viability at high concentrations. Plant Physiol. Biochem. 2015, 94, 191-196. [CrossRef] [PubMed]

41. Arnao, M.B.; Hernández-Ruiz, J. Growth conditions determine different melatonin levels in Lupinus albus L. J. Pineal Res. 2013, 55, 149-155. [CrossRef] [PubMed]

42. Hernández-Ruiz, J.; Cano, A.; Arnao, M.B. Melatonin acts as a growth-stimulating compound in some monocot species. J. Pineal Res. 2005, 39, 137-142. [CrossRef] [PubMed]

43. González-Gómez, D.; Lozano, M.; Fernández-León, M.; Ayuso, M.; Bernalte, M.; Rodríguez, A. Detection and quantification of melatonin and serotonin in eight sweet cherry cultivars (Prunus avium L.). Eur. Food Res. Technol. 2009, 229, 223-229. [CrossRef]

44. Riga, P.; Medina, S.; García-Flores, L.A.; Gil-Izquierdo, Á. Melatonin content of pepper and tomato fruits: Effects of cultivar and solar radiation. Food Chem. 2014, 156, 347-352. [CrossRef] [PubMed]

45. Jinying, W.; Chuan, J.; Shuke, L.; Jingui, Z. Study on analysis method of melatonin and melatonin content in corn and rice seeds. Chin. Agric. Sci. Bull. 2009, 17, 6.

46. Murch, S.J.; Saxena, P.K. A melatonin-rich germplasm line of St John's wort (Hypericum perforatum L.). J. Pineal Res. 2006, 41, 284-287. [CrossRef] [PubMed]

47. Mercolini, L.; Mandrioli, R.; Raggi, M.A. Content of melatonin and other antioxidants in grape-related foodstuffs: Measurement using a meps-hplc-f method. J. Pineal Res. 2012, 53, 21-28. [CrossRef] [PubMed]

48. Johns, N.P.; Johns, J.; Porasuphatana, S.; Plaimee, P.; Sae-Teaw, M. Dietary intake of melatonin from tropical fruit altered urinary excretion of 6-sulfatoxymelatonin in healthy volunteers. J. Agric. Food Chem. 2013, 61, 913-919. [CrossRef] [PubMed]

49. Van Tassel, D.L.; Roberts, N.; Lewy, A.; O'neill, S.D. Melatonin in plant organs. J. Pineal Res. 2001, 31, 8-15. [CrossRef] [PubMed]

50. Hernandez-Ruiz, J.; Cano, A.; Arnao, M.B. Melatonin: A growth-stimulating compound present in lupin tissues. Planta 2004, 220, 140-144. [CrossRef] [PubMed]

51. Kolář, J.; Macháčková, I.; Eder, J.; Prinsen, E.; Van Dongen, W.; Van Onckelen, H.; Illnerová, H. Melatonin: Occurrence and daily rhythm in Chenopodium rubrum. Phytochemistry 1997, 44, 1407-1413. [CrossRef]

52. Stege, P.W.; Sombra, L.L.; Messina, G.; Martinez, L.D.; Silva, M.F. Determination of melatonin in wine and plant extracts by capillary electrochromatography with immobilized carboxylic multi-walled carbon nanotubes as stationary phase. Electrophoresis 2010, 31, 2242-2248. [CrossRef] [PubMed] 
53. Stürtz, M.; Cerezo, A.B.; Cantos-Villar, E.; Garcia-Parrilla, M. Determination of the melatonin content of different varieties of tomatoes (Lycopersicon esculentum) and strawberries (Fragaria ananassa). Food Chem. 2011, 127, 1329-1334. [CrossRef] [PubMed]

54. Okazaki, M.; Ezura, H. Profiling of melatonin in the model tomato (Solanum lycopersicum L.) cultivar micro-tom. J. Pineal Res. 2009, 46, 338-343. [CrossRef] [PubMed]

55. Reiter, R.J.; Manchester, L.; Tan, D.-X. Melatonin in walnuts: Influence on levels of melatonin and total antioxidant capacity of blood. Nutrition 2005, 21, 920-924. [CrossRef] [PubMed]

56. Hardeland, R.; Tan, D.X.; Reiter, R.J. Kynuramines, metabolites of melatonin and other indoles: The resurrection of an almost forgotten class of biogenic amines. J. Pineal Res. 2009, 47, 109-126. [CrossRef] [PubMed]

57. Park, S.; Lee, K.; Kim, Y.S.; Back, K. Tryptamine 5-hydroxylase-deficient sekiguchi rice induces synthesis of 5-hydroxytryptophan and n-acetyltryptamine but decreases melatonin biosynthesis during senescence process of detached leaves. J. Pineal Res. 2012, 52, 211-216. [CrossRef] [PubMed]

58. Arnao, M.B.; Hernández-Ruiz, J. Melatonin: Plant growth regulator and/or biostimulator during stress? Trends Plant Sci. 2014, 19, 789-797. [CrossRef] [PubMed]

59. Byeon, Y.; Lee, H.Y.; Lee, K.; Park, S.; Back, K. Cellular localization and kinetics of the rice melatonin biosynthetic enzymes snat and asmt. J. Pineal Res. 2014, 56, 107-114. [CrossRef] [PubMed]

60. Tan, D.-X.; Zheng, X.; Kong, J.; Manchester, L.C.; Hardeland, R.; Kim, S.J.; Xu, X.; Reiter, R.J. Fundamental issues related to the origin of melatonin and melatonin isomers during evolution: Relation to their biological functions. Int. J. Mol. Sci. 2014, 15, 15858-15890. [CrossRef] [PubMed]

61. Hardeland, R. Melatonin in plants and other phototrophs: Advances and gaps concerning the diversity of functions. J. Exp. Bot. 2014, 66, 627-646. [CrossRef] [PubMed]

62. Zhang, N.; Sun, Q.; Zhang, H.; Cao, Y.; Weeda, S.; Ren, S.; Guo, Y.-D. Roles of melatonin in abiotic stress resistance in plants. J. Exp. Bot. 2014, 66, 647-656. [CrossRef] [PubMed]

63. Arnao, M.B.; Hernández-Ruiz, J. The physiological function of melatonin in plants. Plant Signal. Behav. 2006, 1, 89-95. [CrossRef] [PubMed]

64. Chen, Q.; Qi, W.-B.; Reiter, R.J.; Wei, W.; Wang, B.-M. Exogenously applied melatonin stimulates root growth and raises endogenous indoleacetic acid in roots of etiolated seedlings of Brassica juncea. J. Plant Physiol. 2009, 166, 324-328. [CrossRef] [PubMed]

65. Murch, S.; KrishnaRaj, S.; Saxena, P. Tryptophan is a precursor for melatonin and serotonin biosynthesis in in vitro regenerated St. John's wort (Hypericum perforatum L. Cv. Anthos) plants. Plant Cell Rep. 2000, 19, 698-704. [CrossRef] [PubMed]

66. Murch, S.J.; Saxena, P.K. Melatonin: A potential regulator of plant growth and development? In Vitro Cell. Dev.-Plant 2002, 38, 531-536. [CrossRef]

67. Okazaki, M.; Higuchi, K.; Aouini, A.; Ezura, H. Lowering intercellular melatonin levels by transgenic analysis of indoleamine 2, 3-dioxygenase from rice in tomato plants. J. Pineal Res. 2010, 49, 239-247. [CrossRef] [PubMed]

68. Wang, L.; Zhao, Y.; Reiter, R.J.; He, C.; Liu, G.; Lei, Q.; Zuo, B.; Zheng, X.D.; Li, Q.; Kong, J. Changes in melatonin levels in transgenic 'micro-tom'tomato overexpressing ovine aanat and ovine hiomt genes. J. Pineal Res. 2014, 56, 134-142. [CrossRef] [PubMed]

69. Hernández-Ruiz, J.; Arnao, M.B. Melatonin stimulates the expansion of Etiolated lupin cotyledons. Plant Growth Regul. 2008, 55, 29-34. [CrossRef]

70. Park, S.; Back, K. Melatonin promotes seminal root elongation and root growth in transgenic rice after germination. J. Pineal Res. 2012, 53, 385-389. [CrossRef] [PubMed]

71. Sarropoulou, V.N.; Therios, I.N.; Dimassi-Theriou, K.N. Melatonin promotes adventitious root regeneration in in vitro shoot tip explants of the commercial sweet cherry rootstocks cab-6p (Prunus cerasus L.), gisela 6 (P. cerasus $\times$ P. canescens), and mxm 60 (P. avium $\times$ P. mahaleb). J. Pineal Res. 2012, 52, 38-46. [CrossRef] [PubMed]

72. Reiter, R.J.; Tan, D.-X.; Zhou, Z.; Cruz, M.H.C.; Fuentes-Broto, L.; Galano, A. Phytomelatonin: Assisting plants to survive and thrive. Molecules 2015, 20, 7396-7437. [CrossRef] [PubMed]

73. Jones, M.P.; Cao, J.; O’Brien, R.; Murch, S.J.; Saxena, P.K. The mode of action of thidiazuron: Auxins, indoleamines, and ion channels in the regeneration of Echinacea purpurea L. Plant Cell Rep. 2007, 26, 1481-1490. [CrossRef] [PubMed] 
74. Murch, S.J.; Alan, A.R.; Cao, J.; Saxena, P.K. Melatonin and serotonin in flowers and fruits of Datura metel L. J. Pineal Res. 2009, 47, 277-283. [CrossRef] [PubMed]

75. Murch, S.J.; Hall, B.A.; Le, C.H.; Saxena, P.K. Changes in the levels of indoleamine phytochemicals during véraison and ripening of wine grapes. J. Pineal Res. 2010, 49, 95-100. [CrossRef] [PubMed]

76. Ianăş, O.; Olinescu, R.; Bădescu, I. Melatonin involvement in oxidative processes. Endocrinologie 1991, 29, 147-153. [PubMed]

77. Galano, A.; Tan, D.X.; Reiter, R.J. Melatonin as a natural ally against oxidative stress: A physicochemical examination. J. Pineal Res. 2011, 51, 1-16. [CrossRef] [PubMed]

78. Galano, A.; Tan, D.X.; Reiter, R.J. On the free radical scavenging activities of melatonin's metabolites, afmk and amk. J. Pineal Res. 2013, 54, 245-257. [CrossRef] [PubMed]

79. Tan, D.-X.; Manchester, L.C.; Reiter, R.J.; Qi, W.-B.; Karbownik, M.; Calvo, J.R. Significance of melatonin in antioxidative defense system: Reactions and products. Neurosignals 2000, 9, 137-159. [CrossRef] [PubMed]

80. Poeggeler, B.; Reiter, R.; Hardeland, R.; Tan, D.-X.; Barlow-Walden, L. Melatonin and structurally-related, endogenous indoles act as potent electron donors and radical scavengers in vitro. Redox Rep. 1996, 2, 179-184. [CrossRef] [PubMed]

81. Kolář, J.; Macháčková, I. Melatonin in higher plants: Occurrence and possible functions. J. Pineal Res. 2005, 39, 333-341. [CrossRef] [PubMed]

82. Poeggeler, B.; Thuermann, S.; Dose, A.; Schoenke, M.; Burkhardt, S.; Hardeland, R. Melatonin's unique radical scavenging properties-roles of its functional substituents as revealed by a comparison with its structural analogs. J. Pineal Res. 2002, 33, 20-30. [CrossRef] [PubMed]

83. Shi, H.; Tan, D.X.; Reiter, R.J.; Ye, T.; Yang, F.; Chan, Z. Melatonin induces class a1 heat-shock factors (hsfa 1s) and their possible involvement of thermotolerance in arabidopsis. J. Pineal Res. 2015, 58, 335-342. [CrossRef] [PubMed]

84. Tan, D.X.; Manchester, L.C.; Terron, M.P.; Flores, L.J.; Reiter, R.J. One molecule, many derivatives: A never-ending interaction of melatonin with reactive oxygen and nitrogen species? J. Pineal Res. 2007, 42, 28-42. [CrossRef] [PubMed]

85. Rodriguez-Naranjo, M.I.; Moyá, M.L.; Cantos-Villar, E.; Garcia-Parrilla, M.C. Comparative evaluation of the antioxidant activity of melatonin and related indoles. J. Food Compos. Anal. 2012, 28, 16-22. [CrossRef]

86. Tan, D.-X.; Manchester, L.C.; Esteban-Zubero, E.; Zhou, Z.; Reiter, R.J. Melatonin as a potent and inducible endogenous antioxidant: Synthesis and metabolism. Molecules 2015, 20, 18886-18906. [CrossRef] [PubMed]

87. Tan, D.-X. Melatonin and plants. J. Exp. Bot. 2015, 66, 625-626. [CrossRef]

88. Shi, H.; Chen, Y.; Tan, D.X.; Reiter, R.J.; Chan, Z.; He, C. Melatonin induces nitric oxide and the potential mechanisms relate to innate immunity against bacterial pathogen infection in arabidopsis. J. Pineal Res. 2015, 59, 102-108. [CrossRef] [PubMed]

89. Mittler, R.; Vanderauwera, S.; Suzuki, N.; Miller, G.; Tognetti, V.B.; Vandepoele, K.; Gollery, M.; Shulaev, V.; Van Breusegem, F. Ros signaling: The new wave? Trends Plant Sci. 2011, 16, 300-309. [CrossRef] [PubMed]

90. Dietz, K.-J.; Mittler, R.; Noctor, G. Recent progress in understanding the role of reactive oxygen species in plant cell signaling. Plant Physiol. 2016, 171, 1535-1539. [CrossRef] [PubMed]

91. Tan, D.-X.; Hardeland, R.; Manchester, L.C.; Korkmaz, A.; Ma, S.; Rosales-Corral, S.; Reiter, R.J. Functional roles of melatonin in plants, and perspectives in nutritional and agricultural science. J. Exp. Bot. 2011, 63, 577-597. [CrossRef] [PubMed]

92. Dixit, P.; Mukherjee, P.K.; Sherkhane, P.D.; Kale, S.P.; Eapen, S. Enhanced tolerance and remediation of anthracene by transgenic tobacco plants expressing a fungal glutathione transferase gene. J. Hazard. Mater. 2011, 192, 270-276. [CrossRef] [PubMed]

93. Shi, H.; Jiang, C.; Ye, T.; Tan, D.-X.; Reiter, R.J.; Zhang, H.; Liu, R.; Chan, Z. Comparative physiological, metabolomic, and transcriptomic analyses reveal mechanisms of improved abiotic stress resistance in bermudagrass [Cynodon dactylon (L). Pers.] by exogenous melatonin. J. Exp. Bot. 2014, 66, 681-694. [CrossRef] [PubMed]

94. Wei, W.; Li, Q.-T.; Chu, Y.-N.; Reiter, R.J.; Yu, X.-M.; Zhu, D.-H.; Zhang, W.-K.; Ma, B.; Lin, Q.; Zhang, J.-S. Melatonin enhances plant growth and abiotic stress tolerance in soybean plants. J. Exp. Bot. 2014, 66, 695-707. [CrossRef] [PubMed] 
95. Szafrańska, K.; Glińska, S.; Janas, K. Ameliorative effect of melatonin on meristematic cells of chilled and re-warmed Vigna radiata roots. Biol. Plantarum 2013, 57, 91-96. [CrossRef]

96. Park, S.; Byeon, Y.; Back, K. Functional analyses of three asmt gene family members in rice plants. J. Pineal Res. 2013, 55, 409-415. [CrossRef] [PubMed]

97. Lee, K.; Back, K. Overexpression of rice serotonin n-acetyltransferase 1 in transgenic rice plants confers resistance to cadmium and senescence and increases grain yield. J. Pineal Res. 2017, 62, e12392. [CrossRef] [PubMed]

98. Zuo, B.; Zheng, X.; He, P.; Wang, L.; Lei, Q.; Feng, C.; Zhou, J.; Li, Q.; Han, Z.; Kong, J. Overexpression of mzasmt improves melatonin production and enhances drought tolerance in transgenic Arabidopsis thaliana plants. J. Pineal Res. 2014, 57, 408-417. [CrossRef] [PubMed]

99. Weeda, S.; Zhang, N.; Zhao, X.; Ndip, G.; Guo, Y.; Buck, G.A.; Fu, C.; Ren, S. Arabidopsis transcriptome analysis reveals key roles of melatonin in plant defense systems. PLoS ONE 2014, 9, e93462. [CrossRef] [PubMed]

100. Wang, P.; Sun, X.; Li, C.; Wei, Z.; Liang, D.; Ma, F. Long-term exogenous application of melatonin delays drought-induced leaf senescence in apple. J. Pineal Res. 2013, 54, 292-302. [CrossRef] [PubMed]

101. Zheng, X.; Tan, D.X.; Allan, A.C.; Zuo, B.; Zhao, Y.; Reiter, R.J.; Wang, L.; Wang, Z.; Guo, Y.; Zhou, J. Chloroplastic biosynthesis of melatonin and its involvement in protection of plants from salt stress. Sci. Rep. 2017, 7, 41236. [CrossRef] [PubMed]

102. Bajwa, V.S.; Shukla, M.R.; Sherif, S.M.; Murch, S.J.; Saxena, P.K. Role of melatonin in alleviating cold stress in Arabidopsis thaliana. J. Pineal Res. 2014, 56, 238-245. [CrossRef] [PubMed]

103. Li, J.; Zeng, L.; Cheng, Y.; Lu, G.; Fu, G.; Ma, H.; Liu, Q.; Zhang, X.; Zou, X.; Li, C. Exogenous melatonin alleviates damage from drought stress in Brassica napus L.(rapeseed) seedlings. Acta Physiol. Plant. 2018, 40, 43. [CrossRef]

104. Zhou, X.; Zhao, H.; Cao, K.; Hu, L.; Du, T.; Baluška, F.; Zou, Z. Beneficial roles of melatonin on redox regulation of photosynthetic electron transport and synthesis of $\mathrm{d} 1$ protein in tomato seedlings under salt stress. Front. Plant Sci. 2016, 7, 1823. [CrossRef] [PubMed]

105. Liu, N.; Jin, Z.; Wang, S.; Gong, B.; Wen, D.; Wang, X.; Wei, M.; Shi, Q. Sodic alkaline stress mitigation with exogenous melatonin involves reactive oxygen metabolism and ion homeostasis in tomato. Sci. Hortic. 2015, 181, 18-25. [CrossRef]

106. Liu, J.; Wang, W.; Wang, L.; Sun, Y. Exogenous melatonin improves seedling health index and drought tolerance in tomato. Plant Growth Regul. 2015, 77, 317-326. [CrossRef]

107. Xu, W.; Cai, S.Y.; Zhang, Y.; Wang, Y.; Ahammed, G.J.; Xia, X.J.; Shi, K.; Zhou, Y.H.; Yu, J.Q.; Reiter, R.J. Melatonin enhances thermotolerance by promoting cellular protein protection in tomato plants. J. Pineal Res. 2016, 61, 457-469. [CrossRef] [PubMed]

108. Ding, F.; Liu, B.; Zhang, S. Exogenous melatonin ameliorates cold-induced damage in tomato plants. Sci. Hortic. 2017, 219, 264-271. [CrossRef]

109. Hasan, M.K.; Ahammed, G.J.; Yin, L.; Shi, K.; Xia, X.; Zhou, Y.; Yu, J.; Zhou, J. Melatonin mitigates cadmium phytotoxicity through modulation of phytochelatins biosynthesis, vacuolar sequestration, and antioxidant potential in Solanum lycopersicum L. Front. Plant Sci. 2015, 6, 601. [CrossRef] [PubMed]

110. Zhang, S.; Zheng, X.; Reiter, R.J.; Feng, S.; Wang, Y.; Liu, S.; Jin, L.; Li, Z.; Datla, R.; Ren, M. Melatonin attenuates potato late blight by disrupting cell growth, stress tolerance, fungicide susceptibility and homeostasis of gene expression in Phytophthora infestans. Front. Plant Sci. 2017, 8, 1993. [CrossRef] [PubMed]

111. Wang, L.; Liu, J.; Wang, W.; Sun, Y. Exogenous melatonin improves growth and photosynthetic capacity of cucumber under salinity-induced stress. Photosynthetica 2016, 54, 19-27. [CrossRef]

112. Zhang, R.; Sun, Y.; Liu, Z.; Jin, W.; Sun, Y. Effects of melatonin on seedling growth, mineral nutrition, and nitrogen metabolism in cucumber under nitrate stress. J. Pineal Res. 2017, 62, e12403. [CrossRef] [PubMed]

113. Zhang, N.; Zhao, B.; Zhang, H.J.; Weeda, S.; Yang, C.; Yang, Z.C.; Ren, S.; Guo, Y.D. Melatonin promotes water-stress tolerance, lateral root formation, and seed germination in cucumber (Cucumis sativus L.). J. Pineal Res. 2013, 54, 15-23. [CrossRef] [PubMed]

114. Zhao, H.; Zhang, K.; Zhou, X.; Xi, L.; Wang, Y.; Xu, H.; Pan, T.; Zou, Z. Melatonin alleviates chilling stress in cucumber seedlings by up-regulation of cszat12 and modulation of polyamine and abscisic acid metabolism. Sci. Rep. 2017, 7, 4998. [CrossRef] [PubMed] 
115. Li, H.; Chang, J.; Zheng, J.; Dong, Y.; Liu, Q.; Yang, X.; Wei, C.; Zhang, Y.; Ma, J.; Zhang, X. Local melatonin application induces cold tolerance in distant organs of Citrullus lanatus L. Via long distance transport. Sci. Rep. 2017, 7, 40858. [CrossRef] [PubMed]

116. Nawaz, M.A.; Jiao, Y.; Chen, C.; Shireen, F.; Zheng, Z.; Imtiaz, M.; Bie, Z.; Huang, Y. Melatonin pretreatment improves vanadium stress tolerance of watermelon seedlings by reducing vanadium concentration in the leaves and regulating melatonin biosynthesis and antioxidant-related gene expression. J. Plant Physiol. 2018, 220, 115-127. [CrossRef] [PubMed]

117. Han, Q.-H.; Huang, B.; Ding, C.-B.; Zhang, Z.-W.; Chen, Y.-E.; Hu, C.; Zhou, L.-J.; Huang, Y.; Liao, J.-Q.; Yuan, S. Effects of melatonin on anti-oxidative systems and photosystem ii in cold-stressed rice seedlings. Front. Plant Sci. 2017, 8, 785. [CrossRef] [PubMed]

118. Lee, H.J.; Back, K. 2-hydroxymelatonin promotes the resistance of rice plant to multiple simultaneous abiotic stresses (combined cold and drought). J. Pineal Res. 2016, 61, 303-316. [CrossRef] [PubMed]

119. Li, X.; Brestic, M.; Tan, D.X.; Zivcak, M.; Zhu, X.; Liu, S.; Song, F.; Reiter, R.J.; Liu, F. Melatonin alleviates low ps i-limited carbon assimilation under elevated co 2 and enhances the cold tolerance of offspring in chlorophyll b-deficient mutant wheat. J. Pineal Res. 2018, 64, e12453. [CrossRef] [PubMed]

120. Zuo, Z.; Sun, L.; Wang, T.; Miao, P.; Zhu, X.; Liu, S.; Song, F.; Mao, H.; Li, X. Melatonin improves the photosynthetic carbon assimilation and antioxidant capacity in wheat exposed to nano-zno stress. Molecules 2017, 22, 1727. [CrossRef] [PubMed]

121. Chen, Y.E.; Mao, J.J.; Sun, L.Q.; Huang, B.; Ding, C.B.; Gu, Y.; Liao, J.Q.; Hu, C.; Zhang, Z.W.; Yuan, S. Exogenous melatonin enhances salt stress tolerance in maize seedlings by improving antioxidant and photosynthetic capacity. Physiol. Plant. 2018, 164, 349-363. [CrossRef] [PubMed]

122. Ye, J.; Wang, S.; Deng, X.; Yin, L.; Xiong, B.; Wang, X. Melatonin increased maize (Zea mays L.) seedling drought tolerance by alleviating drought-induced photosynthetic inhibition and oxidative damage. Acta Physiol. Plant. 2016, 38, 48. [CrossRef]

123. Zhang, J.; Shi, Y.; Zhang, X.; Du, H.; Xu, B.; Huang, B. Melatonin suppression of heat-induced leaf senescence involves changes in abscisic acid and cytokinin biosynthesis and signaling pathways in perennial ryegrass (Lolium perenne L.). Environ. Exp. Bot. 2017, 138, 36-45. [CrossRef]

124. Alam, M.N.; Zhang, L.; Yang, L.; Islam, M.R.; Liu, Y.; Luo, H.; Yang, P.; Wang, Q.; Chan, Z. Transcriptomic profiling of tall fescue in response to heat stress and improved thermotolerance by melatonin and 24-epibrassinolide. BMC Genomics 2018, 19, 224. [CrossRef] [PubMed]

125. Gao, W.; Zhang, Y.; Feng, Z.; Bai, Q.; He, J.; Wang, Y. Effects of melatonin on antioxidant capacity in naked oat seedlings under drought stress. Molecules 2018, 23, 1580. [CrossRef] [PubMed]

126. Antoniou, C.; Chatzimichail, G.; Xenofontos, R.; Pavlou, J.J.; Panagiotou, E.; Christou, A.; Fotopoulos, V. Melatonin systemically ameliorates drought stress-induced damage in Medicago sativa plants by modulating nitro-oxidative homeostasis and proline metabolism. J. Pineal Res. 2017, 62, e12401. [CrossRef] [PubMed]

127. Gu, Q.; Chen, Z.; Yu, X.; Cui, W.; Pan, J.; Zhao, G.; Xu, S.; Wang, R.; Shen, W. Melatonin confers plant tolerance against cadmium stress via the decrease of cadmium accumulation and reestablishment of microrna-mediated redox homeostasis. Plant Sci. 2017, 261, 28-37. [CrossRef] [PubMed]

128. Arora, D.; Bhatla, S.C. Melatonin and nitric oxide regulate sunflower seedling growth under salt stress accompanying differential expression of $\mathrm{cu} / \mathrm{zn}$ sod and $\mathrm{mn}$ sod. Free Radical Bio. Med. 2017, 106, 315-328. [CrossRef] [PubMed]

129. Li, C.; Wang, P.; Wei, Z.; Liang, D.; Liu, C.; Yin, L.; Jia, D.; Fu, M.; Ma, F. The mitigation effects of exogenous melatonin on salinity-induced stress in Malus hupehensis. J. Pineal Res. 2012, 53, 298-306. [CrossRef] [PubMed]

130. Gong, X.; Shi, S.; Dou, F.; Song, Y.; Ma, F. Exogenous melatonin alleviates alkaline stress in malus hupehensis rehd. By regulating the biosynthesis of polyamines. Molecules 2017, 22, 1542. [CrossRef] [PubMed]

131. Gao, H.; Lu, Z.; Yang, Y.; Wang, D.; Yang, T.; Cao, M.; Cao, W. Melatonin treatment reduces chilling injury in peach fruit through its regulation of membrane fatty acid contents and phenolic metabolism. Food Chem. 2018, 245, 659-666. [CrossRef] [PubMed]

132. Wei, Y.; Hu, W.; Wang, Q.; Zeng, H.; Li, X.; Yan, Y.; Reiter, R.J.; He, C.; Shi, H. Identification, transcriptional and functional analysis of heat-shock protein 90s in banana (Musa acuminata L.) highlight their novel role in melatonin-mediated plant response to fusarium wilt. J. Pineal Res. 2017, 62, e12367. [CrossRef] [PubMed] 
133. Liang, D.; Gao, F.; Ni, Z.; Lin, L.; Deng, Q.; Tang, Y.; Wang, X.; Luo, X.; Xia, H. Melatonin improves heat tolerance in kiwifruit seedlings through promoting antioxidant enzymatic activity and glutathione s-transferase transcription. Molecules 2018, 23, 584. [CrossRef] [PubMed]

134. Li, X.; Wei, J.-P.; Scott, E.R.; Liu, J.-W.; Guo, S.; Li, Y.; Zhang, L.; Han, W.-Y. Exogenous melatonin alleviates cold stress by promoting antioxidant defense and redox homeostasis in Camellia sinensis L. Molecules 2018, 23, 165. [CrossRef] [PubMed]

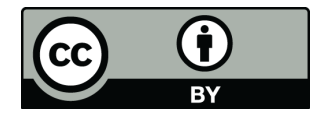

(C) 2019 by the authors. Licensee MDPI, Basel, Switzerland. This article is an open access article distributed under the terms and conditions of the Creative Commons Attribution (CC BY) license (http:/ / creativecommons.org/licenses/by/4.0/). 